\title{
An Assessment of Religion, Peace and Conflict in the Post 1991 of Ethiopia
}

\author{
G.K. Antigegn \\ Bahir Dar University, Bahir Dar, Ethiopia

\section{Оценка религиозной ситуации, мира и конфликта в Эфиопии после 1991 г.}

Научная статья

\section{Г.К. Антигегн}

Университет Бахр-Дара, Бахр-Дар, Эфиопия

\begin{abstract}
Religious violence has become increasingly relevant in political and academic discourses. Because of the revival of religions, the contemporary world cannot be understood without accounting for the role of religion and religious organizations in peace and conflict, including the case of Ethiopia. The purpose of this article is to examine the role of religion in peace and conflict in the post 1991 of Ethiopia. Methodologically, the paper employed qualitative research approach by relying on secondary sources of data. The findings of the research revealed that Ethiopia has many positive assets that have to be exploited fully and critically including the role of the Inter-Religious Council. The religious policies of the present Ethiopian government are remarkably different from any of the previous ones with regard to the measure of religious freedom they provide. Paradoxically, one may wonder why is it at this time, where religious freedom and equality of religion are guaranteed, we are witnessing increased tensions and violent religious conflicts in contemporary Ethiopia. Inter-religious relations in Ethiopia have been peaceful and tolerant for long period. However, the rise of inter-religious conflicts in recent decades is taking place. Generally, in contemporary Ethiopia religion is used both as an instrument for producing conflict in certain circumstances and as a powerful resource for peace and transformation of conflict in the society. On the whole, identifying the role of religion in conflict is a very complex task to accomplish, as there are multiple variables to be well-thought-out.
\end{abstract}

Key words: religion, conflict, peace, violence, inter-religious relations, Ethiopia

For citation: Antigegn, G.K. (2019). An Assessment of Religion, Peace and Conflict in the Post 1991 of Ethiopia. Vestnik RUDN. International Relations, 19 (4), 607-614. DOI: 10.22363/2313-0660-2019-19-4-607-614

Проблематика религиозного насилия становится все более актуальной в политических и академических дискуссиях. Из-за возрождения религиозного фактора современные международные реалии невозможно понять без учета роли религии и религиозных организаций в поддержании мира и урегулировании конфликтов, как, например, в случае с Эфиопией. Целью данной статьи является изучение роли религии в обеспечении мира и урегулирования конфликтов в Эфиопии после 1991 г. Методологически в работе используются качественные методы исследования с опорой на вторичные источники данных. Результаты исследования выявили множество самых разных положительных факторов, качеств и инструментов, которые необходимо использовать в полной мере, но при этом критически, включая роль Межрелигиозного совета. Религиозная политика нынешнего эфиопского правительства заметно отличается от предыдущих в том, что касается объема предоставляемых религиозных свобод. Парадоксально, но в современной Эфиопии при нынешнем гарантировании религиозной свободы и равенства религий происходит заметный рост напряженности и увеличение насильственных религиозных конфликтов. Межрелигиозные отношения в Эфиопии были мирными и отличались терпимостью в течение длительного периода. Однако в последние десятилетия ситуация изменилась из-за роста межрелигиозных конфликтов. В современной Эфиопии религия используется и как инструмент провоцирования конфликтности в определенных условиях, и как мощный ресурс для установления мира и трансформации конфликтов в обществе. В целом определение роли религии в конфликтах является очень сложной задачей, так как необходимо продумывать и учитывать множество переменных.

Ключевые слова: религия, конфликт, мир, насилие, межрелигиозные отношения, Эфиопия

(C) Antigegn G.K., 2019

(i) This work is licensed under a Creative Commons Attribution 4.0 International License

https://creativecommons.org/licenses/by/4.0/ 
Для цитирования: Antigegn G.K. An Assessment of Religion, Peace and Conflict in the Post 1991 of Ethiopia // Becтник Российского университета дружбы народов. Серия: Международные отношения. 2019. Т. 19. № 4. С. 607-614. DOI: $10.22363 / 2313-0660-2019-19-4-607-614$

\section{Introduction}

In recent years, the issue of religious violence has become increasingly relevant in political and academic discourses [Abbink 1998: 110; 2014: 348; Svensson 2008: 5]. Along similar lines, Tarekegn [2002: 3] has argued against the modernist predictions about the weakening role of religion, the contemporary world has witnessed the revival of religions. Hence, the contemporary world cannot be understood without accounting for the role of religion and religious organizations in peace and conflict. Furthermore, Reychler [1997: 20] has also claimed that in the contemporary world, most of the violent conflicts contain religious elements.

In Africa in general and in the Horn of Africa in particular, religious identities have returned as vigorous constituent elements in communal and political discourse. Thus, a gradual process of people reverting to religion as a frame of reference and often as a direct ideology for political action has become quite evident since [Abbink 2011: 254].

The long history of Ethiopia's robust religious pluralism and peaceful co-existence has been noted by various scholars. According to Levine [1974] for example, Ethiopia is often labeled as a model of religious tolerance despite occasional persecutions of followers of other religions than the Ethiopian Orthodox Church (EOC) which had occupied a privileged status as a state religion up until the 1974 revolution. Nevertheless, irrespective of the constitutionally guaranteed religious freedom and equality of religion, in recent times, we are witnessing increased interreligious tensions and violent conflicts.

As it is argued by many scholars, religion is most probably a category too broad for meaningful analysis. In an attempt to identify factors that can explain the role of religion ${ }^{1}$ in peace making and conflict in the post 1991 Ethiopia, one must acknowledge the fact that peace and conflict are the result of a complex interplay of multiple variables. Hence, religious

1 The term religion implies a vast area and, therefore, for the purpose of this paper we will confine ourselves to institutionalized religions commonly known as classical religions. Even in the field of classical religions, our focus will be on Christianity and Islam. factors are embedded in a complex and dynamic setting of other political, social, economic and cultural conditions.

In this respect, Tarekegn stated that "although religions officially advocate peace and reconciliation, there are persistent and widespread allegations that established religions are involved in violent conflicts. The problem is very complex to unravel, as there is a lot of coupling of religion with society's other structures and interests - political, economic, identity, cultural" [Tarekegn 2002: 3].

Accordingly, the general objective of this paper is to examine and analyze the role of religion in conflict and peace in the post 1991 of Ethiopia. In doing so, the paper mainly attempts to understand the nature of inter-religious relationship and seeks to find out how religions and religious institutions can contribute to peace-building efforts in Ethiopia. Methodologically, the paper is both descriptive and interpretative. It does not try to provide an extensive account of the issue at hand, rather it is a desk research that reviews authoritative works in order to understand and analyze the role of religion in conflict and peace in the post 1991 Ethiopia. Relevant publications were identified and reviewed by consulting secondary resources, including books and journal articles.

\section{Debates on the Role of Religion in Peace and Conflict}

Today, the relationship between religion, conflict and peace becomes an increasingly important area of debates and discussions among scholars and practitioners. Accordingly, there are three basic theoretical assumptions. The first represents the reductionist view; religions are used as an instrument for achieving some other purposes. As such, religious dimensions can always be reduced to real social tensions, rooted in divergent economic interests or social power structures [Svensson 2008: 7]. Thus, most of the violent conflicts are not necessarily religious, but have other causes in economic and political grievances of various communities [Kubai, Tarekegn 2008: 18; Muhabie 2015: 30]. In this respect, religion is exploited or instrumentalized for some political, economic and other purposes. Furthermore, Niels (see: [Kubai, Tarekegn 2008: 18]) has also ar- 
gued that there is a direct link between people's access to state power and the political significance of religion, that is, the more access to state power means the less political importance of religion and the viceversa. Hence, from the reductionist perspective, a proper analysis would reveal the real economic and social issues that lie underneath religious issues [Svensson 2008: 7].

In contrast to the reductionist perspective, the second perspective, the essentialist position suggests that religion in different forms is an essential and a real part of the dynamics of armed conflicts. The essentialist position would see the religious sentiments, identities and cleavages beneath economic and political tensions. According to this perspective religious beliefs are fixed and represent an important unit of analysis. Accordingly, any analysis of conflicts should, therefore, focus on the religious aspects [Svensson 2008: 7]. In this regard, religion is taken as the driving force of conflict.

The third perspective is conditionalistic. According to Svensson [2008: 7] religious issue could play a role in the dynamics of armed conflict under specific conditions. It does not assume that religious aspects are either irrelevant or the core explanatory factors behind the dynamics of armed conflict. Thus, it does not disregard, nor does it exaggerate, religious dynamics when analyzing armed conflicts.

Moreover, scholars have also spoken about "hard" and "soft" sides of the religions [Tarekegn 2002: 7]. For example, Galtung (see: [Kubai, Tarekegn 2008: 18]) considers religion as a reality, which is dualistic in nature and thus composed of both the hard and soft sides. Similarly, Boulding [1986] has argued that "most religions have two distinctly contrasting cultures: the holy war and the peaceable kingdom".

\section{Political Conditions for Religion in Contemporary Ethiopia}

The religious policies of the present Ethiopian government are remarkably different from any of the previous ones with regard to the measure of religious freedom they provide. The government introduced policies aimed at recognizing the country's long-standing religious diversity, providing a public arena for religious groups, and maintaining a sharp division between religion and the state [Haustein, Østebo 2011: 755]. The 1995 Federal
Democratic Republic of Ethiopia's constitution provides religious rights. In this regard, Article 11 marks a clear separation of religion and state, rules out a state religion and provides the assurance of no government interference in religious matters and vice versa. While, Article 27 warrants, freedom of religion, belief and opinion, which includes the right of believers to "establish institutions of religious education and administration in order to propagate and organize their religion". The constitution also opens up the possibility for the recognition of religious marriage ceremonies and of religious courts relating to personal and family issues (Articles 34, 78).

Furthermore, the new policies introduced by EPDRF in 1991 also ended the restrictions on Hajj and on import of religious literature, allowed the construction of mosques and enabled the creation of Islamic organizations, newspapers and magazines [Ahmed 1994: 791; 2006: 12]. In contrast to the previous governments, the EPRDF has sought to accommodate the role of religions in Ethiopian society. It has provided more space for the country's religions, separate from the state and politics, and constitutionally enshrined religious equality and freedom of consciousness.

In addition, organized religious entities cannot be simultaneously eligible to operate as political groupings. Most importantly, the Ethiopian political space does not seem to accommodate faith based parties with clear religious programs. This situation avoids the possibility of stronger connection between religious organizations and political actors and diminishes the possibility of the politicization of religious issues. Paradoxically, one may wonder why is it at this time, where religious freedom and equality of religion are guaranteed, we are witnessing increased tensions and violent conflicts.

\section{Christian-Muslim Relations in Contemporary Ethiopia}

Historically, Christians and Muslims relations in Ethiopia have repeatedly been celebrated as peaceful and tolerant. The culture of religious tolerance is deeply rooted in the Ethiopian socio-cultural fabric. Hence, people are friendly to their fellow citizens, regardless of religious differences. Religious public holidays are warmly celebrated at national level. On religious occasions, the adherents of one religion show best wishes for the others. Neighbors 
spend the day together in a festive mood. They mix much with their neighbors; people are well known for firmly stand together during good and bad times, irrespective of their religious or other social backgrounds.

Of course, this is not the only defining feature of the relations between the Christian and Muslim societies in Ethiopia. As can be gathered from historical records, there have been some setbacks and incidents that slightly tarnished such exemplary relationship, though, by and large they may be attributed to the reigning rulers who had fought for power and economic reasons. Indeed, one cannot also deny the fact that Orthodox Christianity as the traditional official State religion of the past imperial regimes; it had advantages over other faiths.

However, contrary to this tradition, in recent decades, we are witnessing the hardest of inter-religious boundaries and the rise of violent interfaith conflicts in different parts of the country. Along similar lines, Abbink [2011: 261] has argued that "in Ethiopia, as in other parts of Africa, relations between Christians and Muslims show a new dynamic under the impact of both state policies and global connections". Thus, religious identities are becoming more dominant as people's primary public identity.

Numerous whys and wherefores are identified for the worsened inter-religious relations in the contemporary Ethiopia. In this respect, Haustein and Østebo [2011: 767] have stated that tensions between Christians and Muslims have often revolved around the construction of mosques and churches. Moreover, controversies over the celebrations of religious holidays have often been sparked by spatial proximity, like that of Kemissie where a procession of Christians celebrating Epiphany came too close to the Muslims preparing for prayer at the town's mosque, resulting in skirmishes with casualties on both sides [Haustein, Østebo 2011: 767].

The inter-religious conflict and the high degree of violence that occurred around Jimma and in Beghi (Wollega) in 2006 and in 2010 came as a surprise to many. The conflict erupted in connection with the celebration of Timket in a village outside of Jimma, and gradually spread to the Beghi area. It resulted in casualties on both sides, churches were burned, and unconfirmed reports tell of Christians being forced to convert to Islam [Haustein, Østebo 2011: 767].
Abbink [2011: 254; 2014: 348] on the other hand, recognizes the nature of religious polemics as the main sources of the problem. According to him, religious polemics in Ethiopia have expressed discursive battles about religious 'truths', communal identities, and power claims that take on a 'primordialist' character and sharpen the boundaries between faith communities and thereby between citizens. The emerging trend of intolerance between followers of different religions can be explained in terms of polemics. In the name of comparative religion some preachers unfairly criticize other religions' doctrines and deeply held values. Hence, the effects of polemical exchanges in this sense are a redrawing of boundaries, discursive over-confidence if not recklessness, decline of dialogue and toleration, and deep rivalry, extending into the social and even demographic sphere [Abbink 2011: 254; 2014: 348; Endalew 2014].

Along similar lines, Haustein and Østebo [2011: 757] have also argued that the increased religious activism and fragile inter-religious relations have spurred Protestants, Orthodox and Muslims create their own, and largely competing narratives on the meaning of Ethiopia. Drawing upon Ethiopian historiography in a highly selective manner, each of these narratives has generated particular perceptions of the "other" and politics in general.

From the viewpoint of the government, the rise of religious conflicts in post 1991 Ethiopia is explained as the use of religion as a cover by 'bankrupt' politicians, especially since the contested May 2005 national election. Here, the underlying causes of the inter-religious conflict are presented as nonreligious. This position of the government is expressed by the following speech of the late Prime Minister, Meles Zenawi: "There are destructive forces on both sides that operate under the cover of religion. Among Christians, particularly some followers of the Orthodox Church, there are attempts to interpret Ethiopian history only from a Christian perspective; a perspective which has generated the slogan of 'Ethiopia is an Island of Christianity'. This position is exclusive and is anathema of religious equality. This is in fact a sick perspective. Similarly, among Muslim circles, there are even forces who want to destroy by force the homegrown Islam [Sufism]" (see: [Ahmed 1994: 791]).

Accordingly, religion is not considered as the essential cause of the inter-religious conflicts in Ethi- 
opia. Rather, both the Islamist and Christian extremist groups are regarded as deliberately misinterpreting Ethiopia's current socio-political landscape. Thus, the extremist groups are considered by and large products of 'defeated politics' or 'bankrupt politicians' who use religion as a 'mask' for legitimacy. All in all, in order to achieve some other purposes, extremist people use whatever possible means at their disposal to foment hatred, instigate violence wrapping themselves in the flag of religion.

However, researchers like Østebø [2007: 11] have argued that Islamic religious reform movements in Ethiopia are less inclined to struggle for the inclusion of Islam in politics than assumed. He further stated that "the rhetoric of a political nature is overtly absent among the Salafis in Ethiopia. Rather than politics, the Salafis are focusing on the religious sphere; encouraging a strict adherence to the principle of Tawhid and avoidance of Sufism and indigenous elements within Islam. Although ideologically linked to the Salafi doctrines underscoring the sharia's as the only legitimate law, the Salafis do not advocate a similar system for Ethiopia. Recognizing the religious plurality of Ethiopia, the prevailing view among Ethiopian Salafis is that religious freedom for all could only be secured under a secular government. Although an expansion of the sharia's-court's jurisdiction would be welcomed by most Salafis, and where more radical elements even would include corporal punishments, the Salafis at large realize that the infusion of the sharia's into the governing system would be impossible in Ethiopia" [Østebø 2007: 11].

Yet, such explanations have failed to consider the reality on the ground in which some radicals are claiming the notion of exclusiveness. For example, the violent clashes erupted in Jimma and Beghi in the fall of 1996 was apparently initiated by elements within the Salafi movement, and it is generally assumed that radical segments of the movement have been fuelling other conflicts as well [Abbink 2011: 254; Dereje 2012: 1895]. Furthermore, the resurgence of the Takfir Wal-Hijra ${ }^{2}$ in Jimma around 2005

2 Takfir wal-Hijrah first emerged in Egypt in 1977, where its leader, Shukri Mustafa advocated a radical interpretation of Islam, defying any Muslim except his own followers as kafirs. With the appearance of the Takfir wal-Hijrah group in 1994-1995, it seemed that the Salafi-movement would move in a new direction. Introduced by a certain Sheikh Mohammed Amin returning from exile in Sudan 1992, the pointed to a politicization of Islam. Taking an exclusivist position towards both Salafi and Non-Salafi Muslims, the group has moreover assumed a radical position toward the Ethiopian state, seen among others by their refusal to hold identity cards and to pay taxes. When this was stated publicly in 2009 , the government sends the army, leading to violent clashes with the Takfiris and to the imprisonment of allegedly over 1,500 men and women [Haustein, Østebo 2011: 765]. In such circumstances, religion is used to energize a struggle for some other purposes. Yet, the causes of conflicts are often presented as religious, even when the underlying causes are non-religious.

On the other hand, explaining every conflict in terms of a reductionist perspective may involve bias. In this regard, allocations of plots for churches and mosques have produced protests from Muslims and Christians respectively, in some cases leading to clashes between the two communities. For example, since 1992, there have been controversies in the ancient town of Axum over the Muslims' request for permission to construct a mosque there [Østebø 2007: 11; Magesa 2007]. Similar example is also seen in Gondar and Dessie in which there has been a clash between Orthodox Christians and Muslims over land.

There are also critics against the government for not fully succeeded in keeping religions and politics apart. Here, most of the critics against the Ethiopian government commonly condemned the government for supporting Al-Ahbash ${ }^{3}$ and violating the constitutionally nailed 'separation of state and

movement grew strong in the northern town of Gondar in the years 1994 - 1997 — before it spread to Addis Ababa, gaining foothold in the mosque in Terro, a northern suburb of the city. The Takfir was soon able to attract quite a number of followers among the young generation, and for a period the issue of Takfir was on everybody's lips. Distancing themselves from the Christians, they also severed their connections to other Muslims, refusing to pray with them. In accordance with the principles of Takfir in general; the criticism of shirk among fellow Muslims, who subsequently are labeled as nonbelievers (kafirs), the Takfir even refuted other Salafis askafirs, including the leading Salafi ulama of Addis Ababa (see: [Østebo 2007: 7]).

3 Labeling the Salafis and Islamists as deviators from Islam, al-Ahbash views itself as the leading force for moderation (al-i'tidal), advocating religious plurality, stability, and political passivity. It has positive attitudes toward the West; recommending its members to study Western learning and science, which in turn would enable them to "civilize" Islamic society (see: [Østebø 2013: 1045]). 
religion and the right to religious freedoms'. Thus, the government is too condemned for using religion as an instrument for political interests. In this respect Østebø indicated that "the EPRDF-regime has consequently taken a more proactive role with regard to religion. It has actively engaged in intra-religious debates, and a highly interesting aspect is how it deliberately has sought to produce its own conceptualization of Ethiopian Islam. The regime's emerging view of Islam is being clearly conceptualized in the Amharic term "nebaru Islimina". Repeatedly reiterated by Prime Minister Meles Zenawi, the term refers to a home-grown, native, or a traditional form of Ethiopian Islam, viewed as pragmatic, flexible, and apolitical, which is currently under attack by the foreign and intolerant Salafis" [Østebø 2013: 1045].

Moreover, the emergence and growth of Islamic reform movements in Ethiopia have also led to increased intra-religious tensions. The one receiving the most attention is the Salafi movement, ideologically and financially affiliated to Saudi Arabia. The Salafis have been the most ardent critics of traditional Islamic practices in Ethiopia. The movement has fiercely attacked what they regard as the inclusion of indigenous elements and Sufi interpretations of Islam ${ }^{4}$.

The second main reform-movement is the Jama'at al-Tabligh ${ }^{5}$. The third movement of the reform is emerging in the early 1990s, which can be labeled as the Intellectualist movement. In contrast

4 Particularly the pilgrimages to various shrines and celebrations of Mawlid are the majors. These practices, as well as Sufism in general — the main antagonism to Salafism, has been refuted as shirk; as deviations from the true faith. Moreover, the Salafis have agitated for a stricter observance of Islam, with the inclusion of various aspects of the Sunna as compulsory (wajib), notably the growing of beard, the wearing of trousers above the ankles (isbal) and females covering their faces (niqab). The Salafi-movement in Ethiopia has in general subscribed to the mainstream Salafi doctrines of Saudi Arabia (see: [Østebo 2007: 4]).

5 Their activities were facilitated by a certain Sheikh Musa, resulting in the expansion of the movement among the Gurage community in Addis Ababa. In accordance with the movement's general principles, the Tablighin Ethiopia has sought to enhance the Muslims' commitment to Islam, by calling them to attend the prayers in the mosque, to observe the fasting and to uphold the six main principles of Tabligh. The Tabligh has moreover not voiced much criticism towards 'traditional' Islamic practices; rather they are allowed to continue within the movement [Østebo 2007: 4]. to the two other movements, the Intellectualist movement has repeatedly emphasized Islam as a resource for man's life in the temporal and the secular world ${ }^{6}$.

On the other hand, Erlich [2010; Kabha, Erlich 2006] describes that "today, in Ethiopia two varieties of Islam is prevalent. Ethiopian or African Islam, a flexible brand of Islam with a popular set of beliefs, traditions, and customs with the acceptance of Ethiopia and its legitimacy as a land led by a Christian establishment. The second brand of Islam is the fundamentalist and political militant brand which is inspired by and imported from the Middle East. This brand of Islam calls for a boycott of Christian-led Ethiopia and to win Ethiopia for Islam. It is this brand of Islam that was at the forefront in the recent confrontations (2012) between the state and followers of Islam.

According to Abbink [2011: 255] also the 'revivalists' or 'reformists' within the Muslim community rant against the mainstream, Sufist-oriented Islam in Ethiopia, thereby advocating a purist and dogmatic form of Islam tending toward hegemonism and intolerance of others. They are challenging not only the traditional, more Sufist-oriented, Muslim faith and Christianity, but also the secular state.

\section{The Role of Religion in Building Peace in the Contemporary Ethiopia}

There is no doubt that religion has continued to play an increasing role in the dynamics of conflicts in Ethiopia. Religion can evoke deep sensitivities and profound historical memories. Combined with political, tribal, regional identities, religious identities can evoke deep divisions, hatreds and enmities that are, in most cases, passed down through generations. Yet, religion can also provide a powerful resource for peace and transformation of conflict in society [Kubai, Tarekegn 2008: 15; Karbo 2013: 45].

Researchers advocating the use of religion as a peace tool are an increasingly important response to the prominent use of religious differences as a basis for waging disruptive conflict and war. In this regard,

6 Islam is perceived as a comprehensive religion, being relevant for all aspects of life, and where the Muslim is thus expected to be active in various sectors of societal and political life. The believer should participate in the capacity of being a member of society, where his or her conduct is to be guided by Islam, and whereby the society will be influenced by the Islamic virtues [Østebo 2007: 4]. 
Appleby [1999] asserted that the ability of religion to inspire violence is intimately related to its equally impressive power as a force for peace. Appleby [1999: 226] draws attention to the number of social and religious locations available to religious peace activists. They include a strong institutional base in a major religion that reaches across many states, a high office in a single state, local offices and those involved in indigenous traditions. In line with this argument Reychler [1997: 20] indicated that in an effort to understand what religions or religious organizations could do to promote a constructive conflict dynamic one could start by investigating systematically which positive or negative roles they play now. According to Reychler's view, religious organizations have a major impact on inter-communal and international conflicts. Furthermore, Reychler [1997: 30; Karbo 2013: 45] perceives that the primary resources offered by religious peace activists to be moral legitimacy, neutrality, ability to advance other's political standing, and ability to reach the world public opinion.

In spite of the increasing presence of inter-religious conflicts in Ethiopia, there are solid grounds that constitute the base for religious co-existence in Ethiopia. For example, the long-standing religious plurality and the tradition of relatively peaceful coexistence in Ethiopia have undoubtedly been contributed in preventing escalation of inter-religious conflicts. The pattern of shared commonality on the grassroot level, a degree of mutual respect and even, in some areas, transgressions of religious boundaries, in the form of cross-religious marriages and even conversions, have served as important resources in preventing conflicts. Moreover, despite the recent extremist discourse in terms of the religious or theological ideas, the mainstream religions in Ethiopia preach love, peace, tolerance and forgiveness and reject violence.

Furthermore, in the Ethiopian context, there is no religious institution that endorses or opposes candidates for election to public office. Such absence of religious involvement in political campaigns and the higher deference in the political sphere contributes to the creation of peaceful and non-polarized religious landscape. Likewise, religious institutions in Ethiopia can also promote the values of tolerance and living in harmony with others. In this regard, the Inter-Religious Council ${ }^{7}$ of Ethiopia (IRCE) is the leading agency responsible for bringing together, in a collective manner, all faiths and religions to address issues of social exclusion and development in the country. In this regard, Karbo [2013: 50] argues that the establishment of the Inter-religious Dialogue - Ethiopia ${ }^{8}$ by the IRCE is the most progressive development in which interpersonal relationships among the various leaders of member faiths will with develop thorough learning about the cultural, ideological and religious views of each faith.

\section{Conclusion}

The study has examined the role of religion in peace and conflict in the post 1991 Ethiopia. Religious relations in contemporary Ethiopia cannot be understood without accounting for the role of religion and religious organizations in peace and conflict; this is because of the revival of religions. Religion becomes one of the debatable issues among scholars and practitioners on its role in peace and conflict. In doing so, three perspectives on the subject under investigation are identified. Accordingly, the reductionist perspective considers religions as an instrument for achieving some other purposes. In contrast to the reductionist perspective, the essentialist position suggests that religious identities are fixed, and represents an important unit of analysis. The other perspective, conditionalistic view, does not assume religious aspects either as irrelevant or the core explanatory factors.

Furthermore the study has examined the current political conditions for religion in Ethiopia. In this respect, the religious policies of the present Ethiopian government are remarkably different from any of the previous ones with regard to the measure of religious freedom they provide. Paradoxically, one may wonder why is it at this time, where religious freedom

7 Members of the IRCE include the Ethiopian Orthodox Tewahedo Church, the Ethiopian Catholic Church, the Ethiopian Adventist Church, Evangelical Churches Fellowship of Ethiopia, The Ethiopian Evangelical Church Mekane Yesus (EECMY) and the Supreme Council of Islamic Affairs in Ethiopia.

${ }^{8}$ The basis of the IRD-E is focused on three main aspects of religious convictions shared by all members of the group. These include: i) The unity of the human race; ii) The fact of religious pluralism; and, iii) The Ethiopian situation (see: [Karbo 2013: 50]). 
and equality of religion are guaranteed, we are witnessing increased tensions and violent religious conflicts.

Historically inter-religious relation in Ethiopia is peaceful and tolerant. However, we have correspondingly realized the rise of inter-religious conflicts in recent decades. In this regard, the existing numerous whys and wherefores concerning the worsened inter-religious relations are critically examined in the study. With regard to this, one can safely argue that in certain circumstances religion is used as an instrument but not in all. In addition, religion can provide a powerful resource for peace and transformation of conflict in society. As regards the potential source of religious peace, Ethiopia has many positive assets that have to be exploited fully and critically including the role of the Inter-Religious Council of Ethiopia.

Received / Поступила в редакцию: 12.07.2019

Accepted / Принята к публикации: 24.09.2019

\section{References / Библиографический список}

Abbink, J. (1998). A Historical-Anthropological Approach to Islam in Ethiopia: Issues of Identity and Politics. Journal of African Cultural Studies, 11 (2), 109-124.

Abbink, J. (2011). Religion in Public Spaces: Emerging Muslim—Christian Polemics in Ethiopia. African Affairs, 110 (439), $253-274$

Abbink, J. (2014). Religious Freedom and the Political Order: The Ethiopian 'Secular State' and the Containment of Muslim Identity Politics. Journal of Eastern African Studies, 8 (3), 346-365.

Ahmed, H. (1994). Islam and Islamic Discourse in Ethiopia (1973-1993). In: Marcus, H.G. (Eds.). New Trends in Ethiopian Studies. Vol. 1. Lawrenceville, N.J.: Red Sea Press. P. 775-801.

Ahmed, H. (2006). Coexistence and/or Confrontation? Towards A Reappraisal of Christian-Muslim Encounter in Contemporary Ethiopia. Journal of Religion in Africa, 36 (1), 4-22.

Appleby, R.S. (1999). The Ambivalence of the Sacred: Religion, Violence, and Reconciliation. Rowman \& Littlefield Publishers.

Boulding, E. (1986). Two Cultures of Religion as Obstacles to Peace. Zygon, 21 (4), 501-518.

Dereje, F. (2012). The Transnational Politics of the Ethiopian Muslim diaspora. Ethnic and Racial Studies, 35 (11), 1893 - 1913.

Endalew, L. (2014). Ethiopian Customary Dispute Resolution Mechanisms: Forms of Restorative Justice. African Journal on Conflict Resolution, 14 (1), 125-154.

Erlich, H. (2010). Islam and Christianity in the Horn of Africa: Somalia, Ethiopia, Sudan. Lynne Rienner Publishers.

Haustein, J. \& Østebø, T. (2011). EPRDF's Revolutionary Democracy and Religious Plurality: Islam and Christianity in PostDerg Ethiopia. Journal of Eastern African Studies, 5 (4), 755-772.

Kabha, M. \& Erlich, H. (2006). Al-Ahbash and Wahhabiyya: Interpretations of Islam. International Journal of Middle East Studies, 38 (4), 519-538.

Karbo, T. (2013). Religion and Social Cohesion in Ethiopia. International Journal of Peace, 4 (3), 43 - 52.

Kubai, A. \& Tarekegn, A. (2008). Striving in Faith: Christians and Muslims in Africa. Life and peace institute, Uppsala, Sweden.

Levine, D. N. (1974). Greater Ethiopia: the Evolution of a Multiethnic Society, Chicago: University of Chicago Press.

Magesa, L. (2007). Contemporary Catholic Perspectives on Christian-Muslim Relations in Sub-Saharan Africa: The Case of Tanzania. Islam-Christian Muslim Relations, 18 (2), 165-173.

Muhabie, M. (2015). The Root Causes of Conflicts in the Horn of Africa. American Journal of Applied Psychology, 4 (2), $28-34$.

Østebø, T. (2007). The Question of Becoming: Islamic Reform-Movements in Contemporary Ethiopia. CMI Working Paper.

Østebø, T. (2013). Islam and State Relations in Ethiopia: From Containment to the Production of Governmental Islam. Journal of the American Academy of Religion, 8 (4), 1029-1060.

Reychler, L. (1997). Religion and Conflict. International Journal of Peace Studies, 2, 16.

Svensson, I. (2008). Divine Disputes? Exploring the Religious Dimensions of Armed Conflicts. Occasional paper, Life and Peace Institute, Uppsala, Sweden.

Tarekegn, A. (2002). Religion and Culture of Violence. New Routes: A Journal of Peace Research and Action, 3-9. Life and Peace Institute, Uppsala, Sweden.

About the author: Antigegn Getahun Kumie - Assistant Professor and Researcher, Department of Political Science and International Studies, Bahir Dar University, Ethiopia (e-mail: getkumie@yahoo.com).

Сведения об авторе: Антигегн Гетахун Куми - преподаватель, исследователь, факультет политологии и международных исследований, Университет Бахр-Дар, Эфиопия (e-mail: getkumie@yahoo.com). 